\title{
Globalization of National Policy-Making: An International Perspective
}

\author{
Mansour Esmaeil Zaei \\ Panjab University \\ Sector 14, Chandigarh, U.T. - 160014, India \\ doi:10.13165/VPA-14-13-2-11
}

\begin{abstract}
Globalization has had effects on different issues of society, especially in policy and policy-making. Policy-making in this era, i.e. the era of globalization, is different when comparing it with policy-making of other era. It needs policy makers to manage the situation well and look globally instead of thinking just locally. On this basis, the aim of this paper is to study globalization in general and its impacts on the national policy agenda first; then, some global context that has an important role in national policy-making, such as environment, poverty and population growth, aids, drugs, trade and industry, privatization and terrorism, is studied.
\end{abstract}

Keywords: globalization, policy-making, society, policy agenda.

\section{Introduction}

Policy-making is an extremely analytical and political process which involves a complex set of forces. It begins with the ideas people or interest groups have about the actions they want the government to take. In other words, these are the demands or proposals made by interest groups or by other actors upon the political system for action or inaction on some perceived problems. Public policies are being conditioned everywhere by the external environment [19, p. 95-96]. It is impossible to separate the external environmental factors, as they invariably influence the political processes and policy outcomes. The influence, being brought to bear on socio-economic problems of a country by agencies (WHO, ILO, UNEP, UNDP, etc.), the World Bank, the International Monetary Fund, the European Policy 
Forum, the Organization for Economic Cooperation and Development (OECD) and the European Central Bank, etc., is of critical importance in shaping its policies.

\section{The Impact of Global Events on National Policy Agenda}

Developing countries are particularly vulnerable to global events and actions and have come to depend heavily on the international community for financial and technical assistance. Consequently, national policies are interlocked with global issues. As Landell Mills and Serageldin state, "Because poor countries generally have fragile politics and weak systems of accountability, with few autonomous institutions and little power to offset that exercised by the central government, external agencies are potentially key political players, capable of exerting considerable influence [...]" $[9$, p. 308]. The boundaries of the political system are no longer impermeable to outside pressures and influences. Public policy now takes place in a world system as well as in national political systems. The international environment has an added role to play in influencing the national policies. The mass media and international conferences ease the process of policy diffusion. Harrop notes that "The international environment forms much of the context of national policy-making. Policy-makers in each country share a policy context formed by the international economic cycle of prosperity; recession depression and recovery [...] International organizations such as the EC also form an increasingly important part of the context of national policy-making. The policy agenda is also becoming international" [7, p. 263].

As multinational corporations and international organizations come to exercise a great degree of influence, so the capacity of national policy-makers to frame their own agendas in reduced [15]. National issues, such as social welfare, environment, drugs and trade, are items on the national policy agenda which have become global issues. This has been accompanied by increasing transnational cooperation. National policy agenda in a developing country of Iran is now exposed to developed countries. With globalization, there is a greater scope of interaction between a nation state and other countries. A nation state has now come to exercise less control on policy agenda than it was in the second half of the twentieth century. From the national perspective, this means that the policy agenda may be global, but the policy-making and implementation remain national. Thus, there is a new kind of inter-play between transnational companies and the national and world economies. Global issues interact with national issues, which, in turn, interact with the local level. Globalization posits that these layers are becoming even more interactive and permeable and that a new policy is emerging.

For example, in European context, a new policy level is developing in terms of Europeification of national policy-making [2]. Europe's common currency (Euro notes and coins issued by the European Central Bank from 1 January 2002) is expected to open the way to a closer political union among European nations. 
Similarly, most developing countries undertook significant liberalization of their trade regimes during the late 1980s and the 1990s slashing tariffs, reducing nontariff barriers to trade, and privatizing public enterprises under the pressures of the World Bank and European countries.

\section{The Need for a Global Perspective}

It may be noted that the nation of World Politics was central to Harold Laeewell's conception of the policy sciences. In 1951, Lasswell argued that policy sciences should take account of world trends and forces when considering the context of policy problems. He maintained the following: "Indeed, one of the major tasks of the policy sciences today is to follow in detail the processes of social invention, diffusion, and restriction throughout the globe for the sake of estimating the significance of specific events" [11, p. 13]. Writing in 1968, Lasswell also maintained that "As the globe shrinks into interdependence, relying more fully on science and technology, the policy sciences gain significance [...] Interdependence implies that every participant and every item in the social process is affected by the context in which it occurs."

Similarly, Etzioni in 1968 also observed that there was a rising interdependence between nations and economies. But he also felt that "Surprisingly, many social scientists tend to overplay that nation-state as the unit of societal analysis and underplay supranational bonds and controls; above all they tend to take the nationalistic moral community as the community of values" [4, p. 607].

\section{Determinants for Globalism}

As it has been already maintained, the country's "political system" also functions within the "world system". The boundaries of the political system are no longer impermeable to outside pressures and influences. The world has become a single social system as a result of growing ties of interdependence. The point is that there is a new kind of interplay between transnational companies and the national and world economies. To Giddens, transnational corporations, growing economic integration and the globalization of communications and media are major factors that make for globalism [6], [5, p. 519-20], [11, p. 14].

Globalization as a term has gained wide attention and recognition. To Albrow, globalization refers to "all those processes by which the peoples of the world are incorporated into a single world society, global society" [1, p. 9]. He further says that "globalism is one of the forces which assist in the development of globalization". The implications of the nation of globalization are that policy-makers must consider agenda formation and problem definition within a global context. The "policymakers in each country share a policy context formed by the international economic cycle of prosperity, recession, depression and recovery" [7, p. 263]. In a global 
environment, it is possible to speak of the convergence of concerns for which global strategies may be formulated. As such, in a global context, more and more issues will be structured by larger forces outside the nation's constitutional framework of public policy-making.

\section{Policy Agenda in a Global Context}

It is important for policy-makers to take account of global issues when considering the context of policy problems in national setting.

\section{Environment}

Pollution of the air and water, destruction of forests and loss of fertile soil are becoming critical problems with serious consequences for health, food production, productivity, and perhaps even the ability of the earth to support human life. Protection and improvement of the quality of the environment has become a global issue since 1980 s.

To Porter and Brown, the environmental issue is increasingly penetrating policy issues, such as international security, North-South relations and world trade [19, p. 95-96]. Their study shows how the issue has involved the development of new levels of interactions among states to form a "global environmental regime". Because of a growing global environmental stress, there is a sustained pressure on national policy-makers to change or modify their policy positions.

The World Commission on Environment and Development (WCED) observed the following: "The traditional forms of national sovereignty are increasingly challenged by the realities of ecological and economic interdependence. Nowhere is this more true than in the shared ecosystems and in "the global commons those parts of the planet that fall outside national jurisdictions" [24, p. 261].

Industrial growth places pressures on policy-makers to prevent control pollution. International agreements on ways to control pollution and close ties between environmentalists have provided an exchange of information that shapes the policy agenda [18, p. 157-159]. The United Nations Conference on Environment and Development in Brazil in June 1992 produced treaties to control global warming and preserve the diversity of species. The meeting issued the Rio Declaration, setting forth broad principles of environmental protection and sustainable development, and Agenda 21, a detailed plan for combating various environmental problems. In sectors, such as land, fresh water, forests, biodiversity and climate change, the 1997 UN assessment found that conditions either were no better than in 1992 or had worsened.

\section{Poverty and Population Growth}

Developing countries are facing increasingly serious population growth and poverty problems. Despite lower poverty rates, the number of poor people has 
increased largely because of population growth in developing countries, as well as uneven development, and increasing concentration of wealth.

Almost half of the world's population (approximately 2.5 billion) lives on less than $\$ 2$ a day, and one fifth of the world's population (approximately 1.4 billion) live on less than $\$ 1.25$ a day [23]. This horrific level of poverty persists despite unprecedented increase in global wealth in the past century. As the 21st century begins, a growing number of people and rising levels of consumption per capita are dimensions of poverty.

Poverty and population growth have now become global issue. The World Bank's (WB) new strategy proposes, for example, an approach to fighting poverty. The three-pronged approach of the WB focuses on increasing opportunities for people, facilitating their empowerment and enhancing their security [22]. Policymakers and environmentalists now largely agree that efforts to reduce poverty and population growth and to achieve better living standards can be closely linked and are mutually reinforcing. The policy agenda at the global level is now slowing the increase in population and attacking poverty.

Most countries, especially developing ones, have come out with national health policies, which are global in context. As diseases have no barriers, there is the need for international cooperation and national political action by turning statements of principle into specific policies and actions throughout the world.

Family planning is seen as a strategy to reduce population growth. The 1994 International Conference on Population Development (ICPD) programme of action states that "the aim of family planning programmes must be to enable couple and individuals to decide freely and responsibly the number and spacing of their children" with a view to reducing population size [20]. Governments of nations that sign international documents of principles make a commitment to act on these principles. The extent of government attention to such commitments and the amount of money allocated to implementing them, however, vary considerably around the world.

\section{AIDS}

AIDS as a communicable disease has become a serious concern to the international community. ADIS has already killed more than 20 million people, and today 35 million people are living with HIV/AIDS, 23 million of them alone are living in Sub-Saharan Africa. Every day another 7,000 people are infected. And around the world, the epidemic is having a huge effect on GNP.

Since it is a global issue, the policy analyst must find a global solution involving a coordinated international cooperation and national political action. Iohnatan Mann, the Director of the WHO's AIDS Programme, stressed that AIDS has been bringing about a "new paradigm of health, because of four factor: "it is a global problem; it is understood and spoken as a global problem; and it is known worldwide; and AIDS is combated at the truly global level" [12, p. 6-7]. 


\section{Drugs}

The use of drugs has become an equally global concern. Earlier, it was regarded as a social problem and the focus was on seeking a national policy. However, since 1980s drug use has posed a serious menace to the international community and it requires a global cooperation and action [21, p. 192-93]. The international concern has addressed the supply and transportation of drugs from the producer nations, such as Thailand, Afghanistan, Pakistan, Columbia, Peru and Bolivia.

\section{Trade and Industry}

Changes have occurred in industry as a consequence of global changes and shifts. The major sources of global shift are transnational corporations which organize production on a world-wide scale, the policies pursued by national governments and the enabling technologies of transport, communication and production. This has largely weakened the ability of national governments to make policies independently of those changes. Dicken observes the following: "[...] the well-being of nations, regions, cities and other communities depends increasingly no merely on events in their own backyards but on what happens at a much larger geographical scale [...] We need a global perspective" [3, p. 3].

Yet nearly 80 countries containing a third of the world's population are being increasingly marginalized, and over the past 20 years developing countries' share of global trade fell from 0.8 to 0.4 percent [8, p. 9]. The fact is that 2.5 billion people live on less than $\$ 2$ a day, and 1.4 billion live on less than $\$ 1.25$ a day [23]. In this way, international development cannot be achieved.

However, national policy-makers have the task of formulating policies which help create business climate. The global industrial environment interacts with the national political processes, and consequently, national policies are increasingly influenced by activities and events happening well away from the national context. So, the capacity of the national policy-makers to frame their own agendas is considerably reduced.

\section{Privatisation}

The beginning of the 1990s witnessed a marked privatization instead of government control. There has been a renewed emphasis on privatization and competition throughout the world. Governments of most countries, both developed and developing, have adopted policies of (1) transferring government - controlled enterprises to have private sector; and (2) opening up a large number of industries to the private sector to encourage competition [17, p. 275]. Privatization is now fashionable in European community, South and North America, Australia, Asia, Africa, and is gaining popularity in Eastern Europe.

The concept of privatization is ambiguous, as it may imply severe reductions in the size of the public sector and a drastic shrinkage of public ownership of 
key industries [10, p. 186]. Privatization is being driven by the shift of important economic sectors to operation on a global scale. National policy agendas are being shaped by forces of global economic restructuring.

\section{Terrorism}

Terrorism is another global problem, which is spreading like a cancer. In Iran, examples of terrorism are Hypocrites group (MKO), Jundullah in Sistan and Baluchistan Province, PJAK group in west of Iran. In the world, Al-Qaeda, Taliban, Revolutionary Armed forces of Colombia, Ansar al-Sunnah Army, Basque Fatherhood and Freedom are operating as terrorist organizations. Attacks on the World Trade Centre and Pentagon in the United States on 11 September, attacks on India's Parliament on 13 December in 2001, bombings of three subway trains and one bus in the UK on 7 July 2005 and an attack by bombing to Islamic Republic Party office in Iran on 1 October 1982 are four important dates that made the whole world realize that terrorism had challenged the world community.

Sabharwal observed that "Our main enemy in the twenty-first century will be terrorism. Terrorism organizations or countries using them as a front, could explode a stray nuclear warhead or carry out biological or chemical attacks which in turn could cause a chain reaction and bring the world to the brink of destruction" [16].

There were several wars in the last century, including two World Wars, but the first decade of this century saw a radically different scenario - highly motivated groups of people launching attacks on nation-states. The shadowy figure of the terrorist has loomed large in homes and outside, menacingly.

Now, there is the need for global cooperation for fighting global terrorism. For this aim, in September 2006, the UN General Assembly adopted the Global CounterTerrorism Strategy. Then, between November 2010 and May 2012, the Office of the UN Counter-Terrorism Implementation Task Force (CTITF) was established. Also, recently, the second global conference of the national focal points has been held in Geneva, entitled International Counter-Terrorism Focal Points Conference on Addressing Conditions Conducive to the Spread of Terrorism and Promoting Regional Cooperation. Today, countries more than any other time have concluded that they cannot stand alone to fight with this phenomenon. Therefore, more and more are encouraged to international cooperation. An example of such international cooperation is Iran's recent cooperation with Argentina about identifying the perpetrators of terrorist explosions in the AMIA Trade Center.

\section{Other Global Issues}

It may be added that the world is becoming reluctantly internationalist, recognizing that the diversity of domestic social and economic issues (social welfare, trade, industry, agriculture, health, education, nuclear war, famine, etc.) is an item on the national political agenda, which is tied up with global issues. This has been accompanied by growing regionalization and internationalization. The global environment forms much of the context of national policy-making. 


\section{Conclusion}

It is largely felt that in developing democratic countries policy agenda is driven by global forces. Problems arise in a context in which economic and social conditions play a major role in shaping opinions and political strategies. For example, the economics that stuck with the planning model experienced slow growth, stagnation, or worse; the collapse of the socialist economies was but "the final nail in the planning coffin". By the 1990s, countries around the world were actively engaged in privatizing public enterprises.

But the power of decision or policy and the capacity to implement it remains largely within the nation states. There is, therefore, a tension between the spillover, which may be said to be taking place at the global level and the reality of the maintenance of national sovereignty. Against the pressure of global agenda, the fact remains that at times of crisis "governments are prone to withdraw from intergovernmental cooperation and supranational policy-making rather than move positively into closer collaboration" [13, p. 70]. A common issue and problems within a global context may be increasingly identified in international terms, but decision-making and implementation still remain largely within nation states. The global socio-economic framework interacts with the political processes and policies pursued by governments of nation states. The success of nation states in policy performance will diverge notwithstanding the convergence of the global policy concerns.

\section{References}

1. Albrow, M.; King, E. Globalization, Knowledge and Society: Reading from International Sociology. London: Sage, 1990, p. 9.

2. Andersen, S. S.; Eliassen, K. A. Making Policy in Europe: The Europeification of National Policy-Making. 2nd edition. London: Sage, 2001.

3. Dicken, P. Global Shift: Industrial Change in a Turbulent World. London: Paul Chapman, 1988, p.3.

4. Etzioni, A. The Active Society: A Theory of Societal and Political Processes. New York: Free Press, 1968, p. 607.

5. Giddens, A. Sociology. 6th edition. Oxford: Polity Press, 2009, p. 519-20.

6. Giddens, A. The Consequences of Modernity. Cambridge: Polity Press, 1990.

7. Harrop, M. Power and Policy in Liberal Democracies. Cambridge: Cambridge University Press (ed.), 1992, p. 263.

8. Karlsson, M. Annual World Bank Conference on Development Economics 2000. Washington: WB, 2001, p. 9.

9. Landell Mills, P.; Serageldin, I. Governance and the External Factor. World Bank, Proceedings of the World Bank Annual Conference on Development Economics. Washington: WB, 1991, p. 308. 
10. Lane, J. E. The Public Sector. 3rd edition. London: Sage, 2000, p. 186.

11. Lasswell, H. D. The Policy Orientation. In: Learner, D., and Lasswell, H. D. (eds.). The Policy Sciences. Stanford University Press, 1951, p. 13-14.

12. Liss, A. R. The Global Impact of AIDS. York, 1988, p. 6-7.

13. Metcalfe, L.; Richards, S. Evolving Public Management Cultures. In: Kooiman, J., and Eliassen, K. A. (eds.). Managing Public Organizations. London: Sage, 1987, p. 70.

14. Porter, G.; Brown, J.; Chasek, P. S. Global Environmental Politics. Boulder: Westview Press, 2000.

15. Ray, J. Global Politics. 9th edition. Boston: Houghton Mifflin, 2007.

16. Sabharwal, O. P. The Killer Instinct. New Delhi: Roopa, 2002.

17. Sapru, R. K. Development Administration. 2nd edition. New Delhi: Sterling Publishers, 2002, p. 275.

18. Sapru, R. K. Environmental Policy and Politics in India. In: Uday Desai (ed.). Ecological Policy and Politics in Developing Countries. New York: State University of NY Press, 1998, p. 157-59.

19. Sapru, R. K. Public Policy: Formulation, Implementation and Evaluation. 2nd edition. New Delhi: Sterling Publishers, 2011, p. 95-96.

20. United Nations. Programme of Action of the International Conference on Population and Development. Cairo, Egypt, 1995.

21. Woodby, S.; Cottam, M. L. The Changing Agenda: World Politics Since 1945. Boulder: Westview Press, 1991, p. 192-93.

22. World Bank Policy and Research Bulletin, Vol. 11 and Vol. 12, No. 1 and No. 4, October-December 2000 and January-March 2001.

23. World Bank. World Development Indicators Database. Washington: DC, 2008.

24. World Commission on Environment and Development. Our Common Future. 3rd edition. Oxford: OUP, 1987, p. 261.

\section{Mansour Esmaeil Zaei \\ Nacionalinio viešosios politikos formavimo globalizacija: \\ tarptautinė perspektyva}

Anotacija

Globalizacija visuomenę veikia ịvairiais aspektais. Ypatingai globalizacijos įtaka visuomenei pasireiškia per politiką ir viešosios politikos formavimą. Dabartiniu laikmečiu, t. y. globalizacijos epochoje, viešosios politikos formavimas yra kitoks, negu buvo bet kada iki šiol. Šioje eroje politikos formuotojai privalo sugebėti gerai reaguoti i besikeičiančias sąlygas ir mąstyti globaliai, o ne lokaliai. Atsižvelgiant ị tai šio straipsnio tikslas yra (i) išnagrinèti bendruosius globalizacijos bruožus ir jos poveiki nacionalinei viešosios politikos darbotvarkei, (ii) išanalizuoti kai kurias pasaulines, formuojant nacionalinę viešąją politiką reikšmingas tendencijas tokiose srityse, kaip aplinkos apsauga, skurdo didejimas ir gyventojų skaičiaus augimas, AIDS, narkotikų vartojimas, prekyba ir pramoné, privatizacija, terorizmas. 
Mansour Esmaeil Zaei - Pandžabo universiteto Menų fakulteto Viešojo administravimo katedros doktorantas (Pakistanas).

E. paštas: m.esmaeilzaei@gmail.com

Mansour Esmaeil Zaei, Panjab University, Faculty of Arts, Department of Public Administration, $\mathrm{PhD}$ student.

E-mail: m.esmaeilzaei@gmail.com

Straipsnis įteiktas redakcijai $2014 \mathrm{~m}$. balandžio 5 d.; recenzuotas; parengtas spaudai $2014 \mathrm{~m}$. gegužès $21 \mathrm{~d}$. 